ECONOMICS

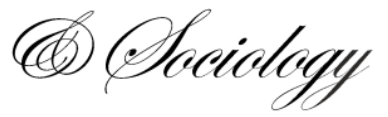

Shkolnyk, I., Kozmenko, S., Kozmenko, O., \& Mershchii, O. (2019). The impact of the economy financialization on the level of economic development of the associate EU member states. Economics and Sociology, 12(4), 43-58. doi:10.14254/2071-789X.2019/12-4/2

\title{
THE IMPACT OF ECONOMY FINANCIALIZATION ON THE LEVEL OF ECONOMIC DEVELOPMENT OF THE ASSOCIATE EU MEMBER STATES
}

Inna Shkolnyk, Sumy State University, Ukraine Email:inna_shkolnik@ukr.net

Serhiy Kozmenko, University of Social Science, Lodr, Poland

University of Customs and Finance, Dnipro, Ukraine E-mail:

kozmenko.uabs@gmail.com

Olga Kozmenko, Kharkiv National University of Economics, Ukraine

E-mail: o.v.kozmenko@gmail.com

Borys Mershchii, Sumy State University, Ukraine

Received: May, 2019

1st Revision: July, 2019

Accepted: November, 2019

DOI: $10.14254 / 2071-$

789X.2019/12-4/2

JEL Classification:C10, G10, O16

\section{Introduction}

ABSTRACT. Dynamic development of the financial system has an increasing impact on the state and development of both national economies and the world economy. This problem is especially acute in developing countries and is predetermined by their economic, social and political development. It also requires constant evaluation and control over the level of their economic development in terms of financialization. Within the framework of the European Neighborhood Policy, the EU cooperates with the countries of the region to deepen and strengthen the relations and helps to increase the stability and sustainability of its Eastern neighbors. Ukraine, Moldova, and Georgia today are currently Associated Eastern Partnership members. Using the panel data for these countries over the period of 2007-2017, the relationship between economic growth and indicators of financialization of the economies was determined. To this end, a fixed-effect regression model, the statistical adequacy of which was confirmed by many indicators (significance levels, Rsquared coefficients, the Breusch-Pagan test), is also used. It was determined that employment, exports of goods and services, added value created in the industrial sector, the ratio of bank capital and reserves to total assets, the share of M1 monetary aggregate in GDP, deposit rate, and Gini index had a positive influence on economic growth of the countries in question.

Keywords: panel data, GLS methods, financial globalization, financial system, industry output, direct investment in the economy, Gini index 
Evolutionary transformational processes in many countries have predetermined the gradually increasing attention to economic development overall and factors stimulating it. Therelevance of this issue has been confirmed by the fact that in 2018, Paul M. Romer and William D. Nordhaus won the Nobel Prize in Economics for studying the relationship between economic growth and technological and climatic changes taking place in a globalized world.

Defining the indicators of economic development is one of the tasks that need constant attention due to the change dynamics. Contemporary economic processes balance between real and financial sectors of the economies. The process of financialization, in its turn, should serve as a service mechanism for the real sector. Dynamic tracking of changes in interests and goals of economic entities becomes a prerequisite for predicting the state of economic development.

The EU is interested in deepening its relations with the Eastern Partnership countries in the context of their two-way cooperation. The closest cooperation in the region is with the EU associate members (Ukraine, Moldova, and Georgia), which are reforming their sociopolitical life to improve population living standards. Today, these partner countries are at the stage of reforming and thus require comprehensive support to prioritize and optimize the allocation of scarce resources to achieve better results. The European Commission identified 20 key deliverables for 2020: economic development and market opportunities, strengthening institutions and good governance, connectivity, energy efficiency, environment and climate change, mobility and people-to-people contacts, etc. The general framework for maintaining relations with the EU is determined by the Association Agreements and the Partnership Priorities. Partners also participate in initiatives such as Erasmus+, TAIEX, Twining, SIGMA and the Neighborhood Investment Facility.

The purpose of the article is to determine the economic growth indicators in the context of economy financialization in the EUassociate member states.

\section{Literature review}

Theories of economic growth are current trends in research at any time, especially in the face of modern dynamic change, and are being explored by scholars from various research areas. Some studies determine the drivers of economic growth.

In particular, Smirnov and Wang (2018) proposed a new (logistic) growth model, which is anatural continuation of previous research on economic growth.

Themba, Chirva, and Nicholas (2016), based on the neoclassical Solow-Swan's (1956) economic growth theory, state that factors that determine the level of economic growth differ depending on the economic level of a country. Besides, the same factors may manifest themselves differently. Various scholars actively explore this model from different perspectives. For example, in addition to labor-intensive technological progress, Liashenko (2013) has included capital-intensive technological progress in this model by introducing an effective capital indicator. In addition, the neutral technological progress is considered by introducing an autonomous multiplier into the production with a given pace of neutral technological progress.

Boldeanu and Constantinescu (2015) explore a wide range of factors that can determine economic growth. These factors were grouped as economic and non-economic. Lychkina (2004) implemented complex stimulation modeling of regional socio-economic development, which makes it possible to develop an optimal system of managerial decisionmaking. Shyrmay (2005) proposed a comprehensive approach to analyzing the impact of technology, population, health care, education, industrial development, international 
assistance, and other factors on the level of socio-economic development. Kooros and Badeaux (2007) conducted a comparative analysis of economic development models. Among the key theories discussed were the Markov chain and the Leontiev-Kooros model, which generally allowed for highlighting the benefits and drawbacks of resource allocation in the process of socio-economic development.

Economic development research involves the use of various economic and mathematical tools. In particular, Iyer and Gupta (2019) analyze the economic development of India using Bayesian vector autoregression (BVAR) techniques. They predict quarterly GDP growth in the country, identify potential vectors for changing the nature of monetary policy, and outline alternative approaches to monetary policy.

Some publications identify the influence of a particular factor on economic growth. Ongoing research tends to reveal the impact of the financial component on economic growth, both globally and nationally. Eddien, Ananzeh, and Othman (2019) examine the impact of financial development on economic growth in a country, using Jordan as an example. They employ various economic and mathematical tools such as Johansen co-integration test (VECM) and Granger causality test. According to the authors, it is important to increase foreign investment, but institutional reforms are needed to improve functioning of the financial sector. Masoud and Hardaker (2012) and Osuji (2015), using regression models, investigate the impact of financial determinants on economic growth in Nigeria. Petkovski and Kjosevski (2013) explored the impact of the financial sector on economic growth in the case of 16 transition economies from Central and South Eastern Europe, using the Generalized Method of Moments (GMM). Karagiannis and Kvedaras (2016) assessed the impact of financial development on economic growth in EU countries.

Some authors try to identify the most important factors from a large list of indicators, usually using panel data. Such studies are more systematic and make it possible to assess the situation more comprehensively and objectively. In particular, the study on the economic growth factors in V4 countries (Czech Republic, Hungary, Poland, and Romania (Simionescu et al. (2016, 2017) Korauš et al. (2017) empirically analyzes data from 2003-2016 using the Bayesian generalized ridge regression. Direct foreign investment, which has essentially contributed to economic development, has been considered a significant factor among a wide range of indicators for these countries, and only in the Czech Republic education spending is the most important driver.

There are studies that specify the prospects for economic growth, as well as the factors that encourage it. Among them, it is worthwhile to highlight Kharlamova et al. (2019) who defined the potential GDP using a production function and one-dimensional and multidimensional Hodrick-Prescott filter to build the trends. They identified that the backlog in the manufacturing industry plays a significant role in monetary policy, acting as an inflation factor.

Vinnychuk et al. (2015) and Bilan et al. (2017) propose a dynamic model of economic growth, taking into account the environmental component.

Many scientists examine economic development through the lens of financial technology (Azarenkova et al., 2018), financial security (Vladychyn et al., 2018), investment security (Blakyta et al., 2018), etc.

Boldyrev et al. (2019) constructed stochastic models of the socio-economic development of regions. Adelman and Morris (1958), one of the founders of econometric modeling of socio-economic changes, considered socio-economic changes in the least developed countries. The Indian scholars Saseendran and Rodríguez (2018) analyzed socioeconomic development in terms of changing human potential. Duman and Kurekova (2012) 
investigated the role of public administration and industrial development in socio-economic development.

Analyzing the role of financialization as an inevitable process in contemporary development is a particular focus of attention ineconomic growth studies. Kozmenko and Korneev (2014) analyze the relationship between the real and financial sectors in the context of financialization. The authors formulate positive and negative effects of the financial sector on the real economy sector, analyze the periods of financialization of the world economy and determine the forecasted effects of financialization of the Ukrainian economy.

Barradas (2019) analyzes the relationship between financialization and labor market in EU countries during 1995-2013. The results point to a gap in the development levels between the financial sector and the labor markets of the countries in question. Alvarez (2015), using panel data from 2004-2013, investigates the relationship between the degree of financialization in France and the uniform distribution of revenues. Peralta and Escalonilla (2011) also analyzed the processes oflabor market change influenced by financialization.

Svilokos and Burin (2017) examined the extent to which financializationaffects deindustrialization in the European Union. The study was based on a fixed-effects regression model in the period of 1995-2015. It was clarified that in the process of financialization, the manufacturing sector is reduced and replaced by service activities. However, the service sector does not compensate for job losses in the manufacturing sector. Besides, financialization negatively affects the added value of the manufacturing sector.

Theoretical analysis of current developments outlined the range of existing scientific and methodological developments in the chosen research area. Most scholars have been found to be in line with key trends in covering the effective features of socio-economic development. Also, a list of existing factors that have an impact on the complex phenomenon under investigation was compiled. Meanwhile, there is a lack of possible directions to expand existing basic models of socio-economic development. In the current study, this will be done through the alternate inclusion of indicators, which should further determine the factors influencing the level of socio-economic development of the country group studied.

The theoretical material developed will be the basis for a practical study that combines basic construction of economic growth models, economic and mathematical tools to determine the interrelationships between productive and factor characteristics. Particular attention is drawn to the process of financializationin the context of economic growth concepts. The theoretical ideas obtained will be the basis for studying economic growth influenced by financialization processes within the EU associate member states, which are in the process of dynamic transformation of social and political life under reforms. Reform requires constant monitoring of factors and results of measures taken to change certain problematic aspects. The results may be a recommendation to draw up a reform roadmap in selected countries as a source for defining particularly promising or problematic indicators of economic growth.

\section{Output data}

The study used data describing the economic development of countries that have a EU Association Agreement. These include Ukraine (the Agreement came into effect on September 1, 2017), Georgia (July 1, 2016), and Republic of Moldova (July 1, 2016). This type of partnership in EU is aimed at the cooperation of associated members and the EU in economic, trade, political and other fields. These countries share the common historical past of the former Soviet republics and countries whose economies are being transformed from command-administrative to market-type ones. According to the World Bank'sincome-based 
classification, these countries are lower- and middle-income economies (Ukraine, Moldova, and Georgia). The impact of economy financialization on the level of economic development in the countries was analyzed for the 2007-2017 period based on the World Development Indicators (WDI), which characterize relevant and accurate global, national and regional assessments compiled from officially recognized international sources.

\section{Methodology}

The choice of the observation period of 2007-2017 for the three countries results in a two-dimensional array with a temporal and spatial component, which makes it necessary to manipulate the panel data. The panel data allow capturing a large number of objects over a period of time. Among the advantages of using panel data, one can highlight the fact that this increases the number of degrees of freedom and, accordingly, reduces collinearity between the explanatory variables, which improves the estimate efficiency. Works by Bassanini and Scarpetta (2001), and Dewan and Hussein (2001) are the examples of using panel data in studying the economic growth factors. The data regression analysis tools of the STATA software complex will make it possible to establish the type of relationship between the studied variables. The regression of these panels implies the possibility of using two types of models: fixed effects and random effects model (Torres-Reyna, 2007). The fixed effects model is most appropriate when investigating a certain unique homogeneous set of observables, whereas the random effects model is more applicable in the case of noncorrelation and heterogeneity of randomly selected observational objects in the total population.

\section{Findings}

The panel data regression model provides a dependent variable and several factor variables. GDP per capita was taken as an indicator of economic growth (dependent variable). The reason for this is that GDP is one of the indicators of economic development and the most complete indicator of the total volume of production of goods and services over a certain period. The United Nations' System of National Accounts 2008 confirms this. The document outlines three possible indicators of economic growth in a country, namely, the volume of gross domestic product (GDP), real gross domestic income, and real gross national income. But the total GDP is only an absolute measure, and GDP per capita is a real indicator of development, which gives grounds for ranking the states according to their economic development.

Given the publicly available statistical information for the period of the study, the following factors were selected that may have an impact on the level of economic development in the countries under investigation:

$\mathrm{X} 1$ - the ratio of employed to total population over the age of 15 (based on the International Labor Organization data) (Employment);

X2 - exports of goods and services (\% of GDP) (Export_of_goods);

$\mathrm{X} 3$-the share of gross value added created in the industry sector (Industry);

X4 - the amount of direct foreign investment (\% of GDP) (dir_invest);

X5 - GDP (n-1 period) (in USD).

The GDP of the previous period was taken with the assumption that it is the basis for economic development in the current period. After collecting statistics on selected metrics, the ratio between them was calculated. As a result, there is a strong or moderate association 
between most of the factors. Consider the results of the relationship between GDP per capita and selected factor variables, using the fixed effects model in the STATA software package.

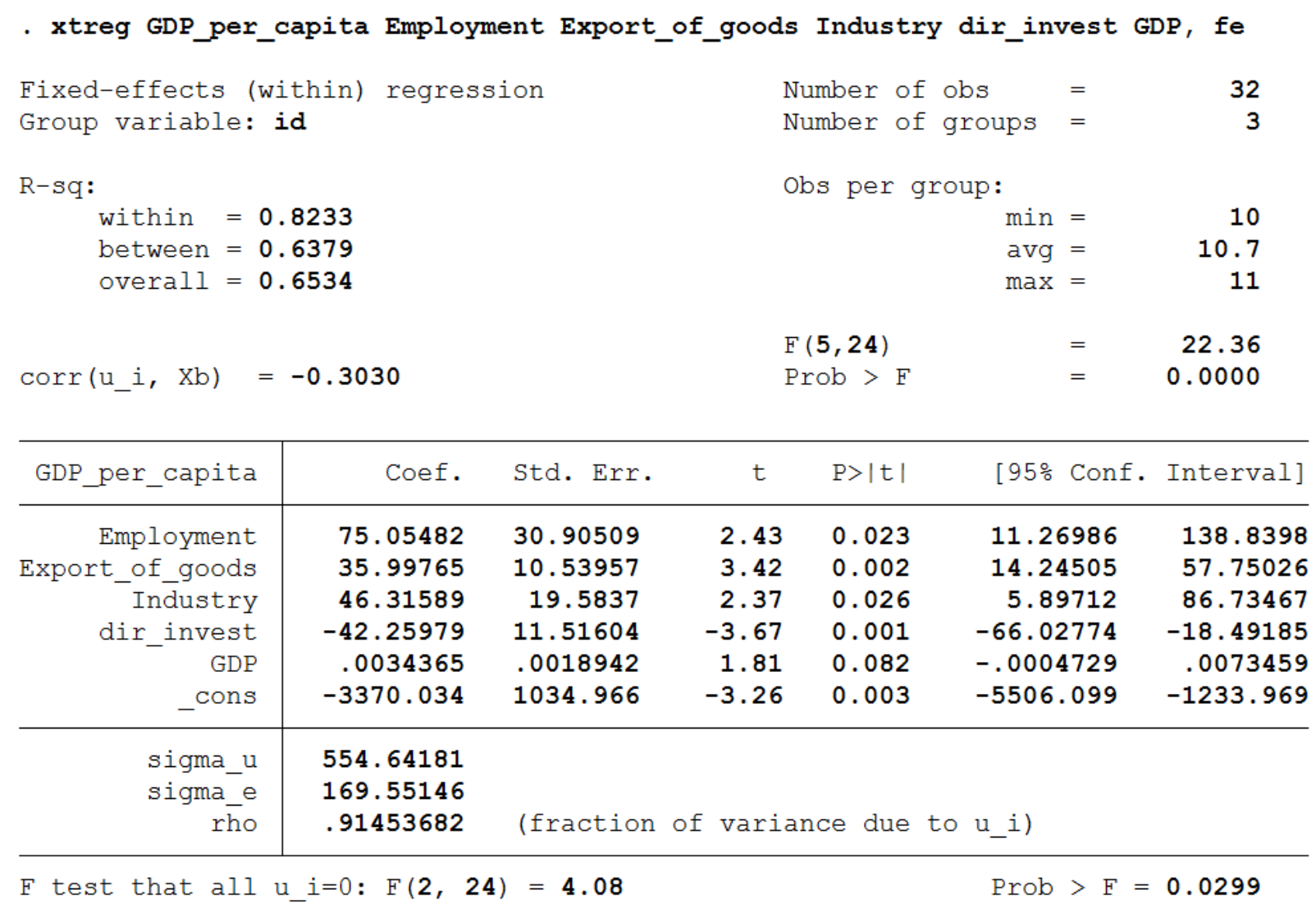

Figure 1. The results of the economic growth and factor characteristics correlation (fixed effects)

Correlation of individual effects, corr $\left(\mathrm{u} \_\mathrm{i}, \mathrm{Xb}\right)=-0.303$, means relatively weak flexibility of the fixed effects model. The quality of fitting of the calculated interrelations between the economic growth indicator and the factor variables is due to the high value of "Rsquared within", which is 0.82 . The "R-squared between" indicator is smaller than previously analyzed and is 0.64 , that is, interindividual differences appear to be worse than dynamic ones.

The random effect model is a compromise between through regression, which imposes great homogeneity constraints on all regression equation coefficients for any $i$ and $t$, and fixed effect regression, which allows each sample object to enter its constant and thus take into account the existing heterogeneity that cannot be observed. In a random effects model (ui random), individual heterogeneity is taken into account not in the equation itself, but in a covariance matrix that has a block-diagonal form, since random effects correlate within each group. Generalized least squares (GLS) method should be used to evaluate such regression. Let's estimatea random effects model for the same set of factor variables. 


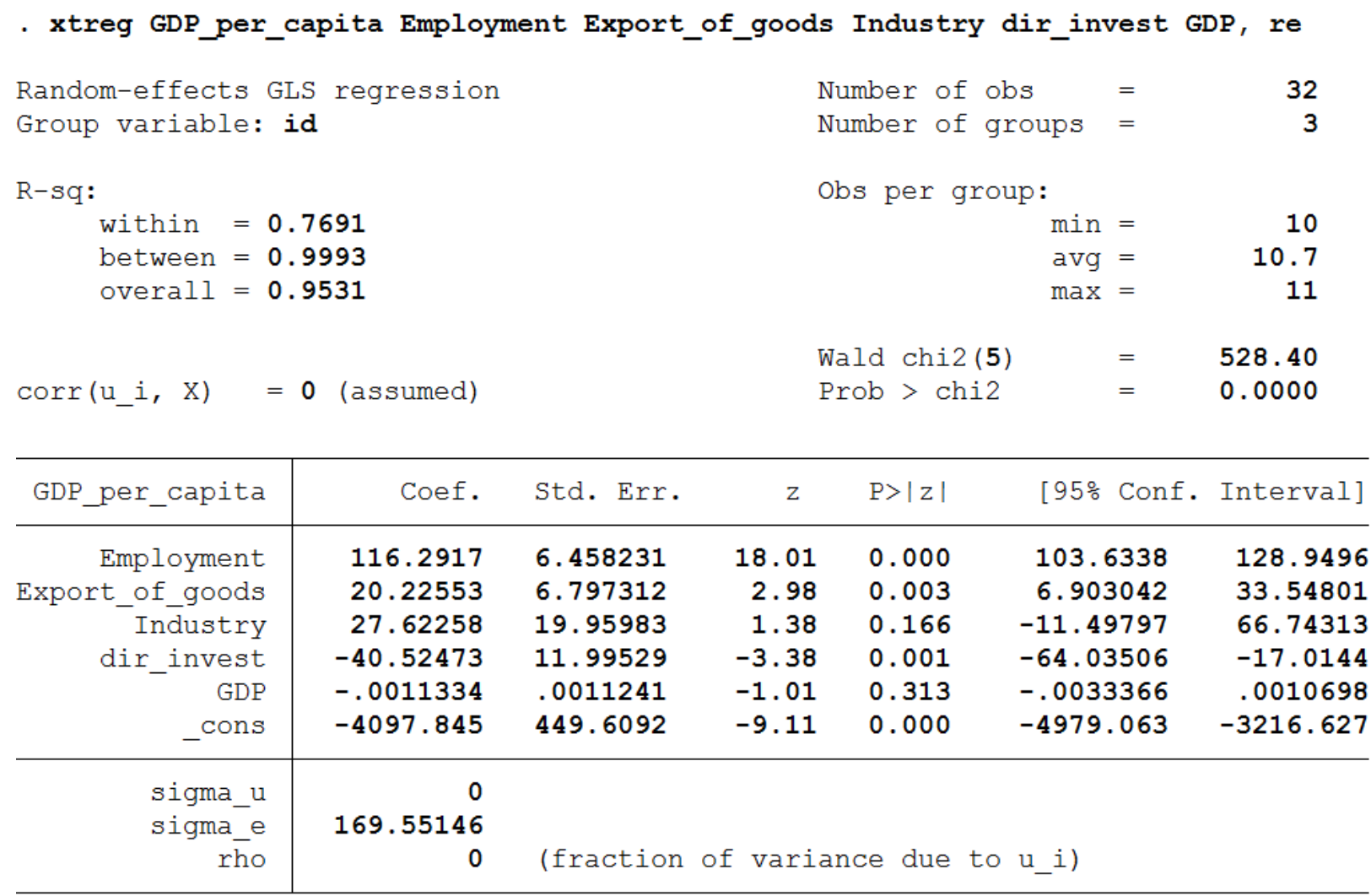

Figure 2. The results of the economic growth and factor characteristics correlation (random effects)

Endogeneity is almost non-existent in the model because the coefficients of the most important variables were significant. Most of the coefficients of the studied variables did not change their sign; only theabsolute size has changed. The value of Wald statistics will be interpreted as R-squared is not an indicator of the adequacy of this type of model. The obtained value of Wald statistics, Waldchi2 $(5)=528.4$, means that none of the regression coefficients is zero. The equation corr $\left(\mathrm{u} \_\mathrm{i}, \mathrm{X}\right)=0$ (assumed) reflects the hypothesis underlying the random effects model: regressors do not correlate with random effects that are not observed.

The analysis of the random effects model is due to the following reasons:

- estimates of the fixed effects model are significant for interconnections in the absence of endogeneity, but it is conceivable that the coefficients will be false for the most critical variables in the study;

- the fixed effects model does not allow estimating the coefficients for timeinvariant regressors, since they are eliminated from the model after the "within" transformation.

The testparm is then used to evaluate the quality of the fixed effects regression. This test makes it possible to determine whether a fixed-effect model applies to this data set. This test is used in the authors' model. It was found that Prob $>\mathrm{F}=0.00$, which is less than 0.05 . This means that time-fixed effects are needed for this set of indicators.

The random effects model was investigated using the Breusch-Pagan test (null hypothesis about the random effects model adequacy). It was found that $\mathrm{p}$-level $=1.000$; this 
indicates that the model does not have random effects, and it is necessary to use a fixed effects model.

This result is due to the fact that specific indicators were chosen for regression, and their composition did not change from year to year. The random effects model may be relevant in the case of non-correlating random effects with regressors. In this case, a large number of indicators correlate with each other.

The following interconnection of economic growth with factor variables was obtained:

$$
Y_{x}=75.1 X_{1}+35.9 X_{2}+46.3 X_{3}-42.3 X_{4}+0.0034 X_{5}-3370 .
$$

In this regression model, the employment rate $(+75.1)$ had the most significant impact on GDP per capita change in this country group. The factor of exports of goods and services has a positive impact on the growth of the dependent variable $(+35.9)$. The share of gross value added created in the industrial sector positively affects the country's economic growth. Foreign direct investment $(-42.3 \%)$ harmed the GDP per capita change rate in the regression. For example using the heterogeneous panel of cointegration methods that are resistant to missing variables and endogenous regressors, D. Herzer revealed that FDI influenced economic growth in 44 developing countries. The main result of his study was that FDI, on average, had a negative impact on economic growth in developing countries, but there were significant differences in effects across countries. The average negative impact in the current model can be explained by the fact that in the present group of countries, there is a specific factor of state intervention, volatility, the significant level of risk and other factors.

The negative impact of investment on the level of economic development in the associate EU member states can be explained by the fact that the investment structure has a certain share originating from offshore zones. Accordingly, there is a suggestion that these funds do not cause real investment impact. The structure of the economies of countries surveyed does not have sufficiently developed high-tech branches with a high proportion of value added. Analyzing the business environment according to Doing Business 2018, Georgia ranks 9th, Moldova 44th and Ukraine 76th. This rating indicates that among the countries in question, there are some barriers in the protection of shareholders' interests, business taxation, enforcement of contractual relations and insolvency issues. Besides, corruption is a negative prerequisite for the investment climate in the countries studied. In particular, the Corruption Perceptions Index 2018 shows that, compared to other countries, Georgia ranks 41st, Moldova 117th, and Ukraine 120th.

Some indicators of financialization may be included in an existing regression of economic growth. In turn, one indicator is regressed to identify the most significant factors. When considering financialization indicators, models were constructed using the following indicators:

$\mathrm{X} 1$ - the ratio of bank capital and reserves to total assets (bkap);

$\mathrm{X} 2$ - the liquid reserves to bank assets ratio (liq_res);

$\mathrm{X} 3$ - the share of non-performing loans in total loan portfolio (nonperf_cred);

X4 - the share of the M1 money aggregate in GDP, \% (cash in circulation and transferable deposits in the national currency) (broad_money);

X5 - deposit rate (dep_rate);

$X 7$ - the amount of loans provided by financial sector (dom_cred);

X8 - Gini index (GINI). 
As a result of the calculations, the most statistically significant were the regressive relations with the following indicators: the ratio of bank capital and reserves to total assets, the share of M1 monetary aggregate in GDP, \%, and Gini index.

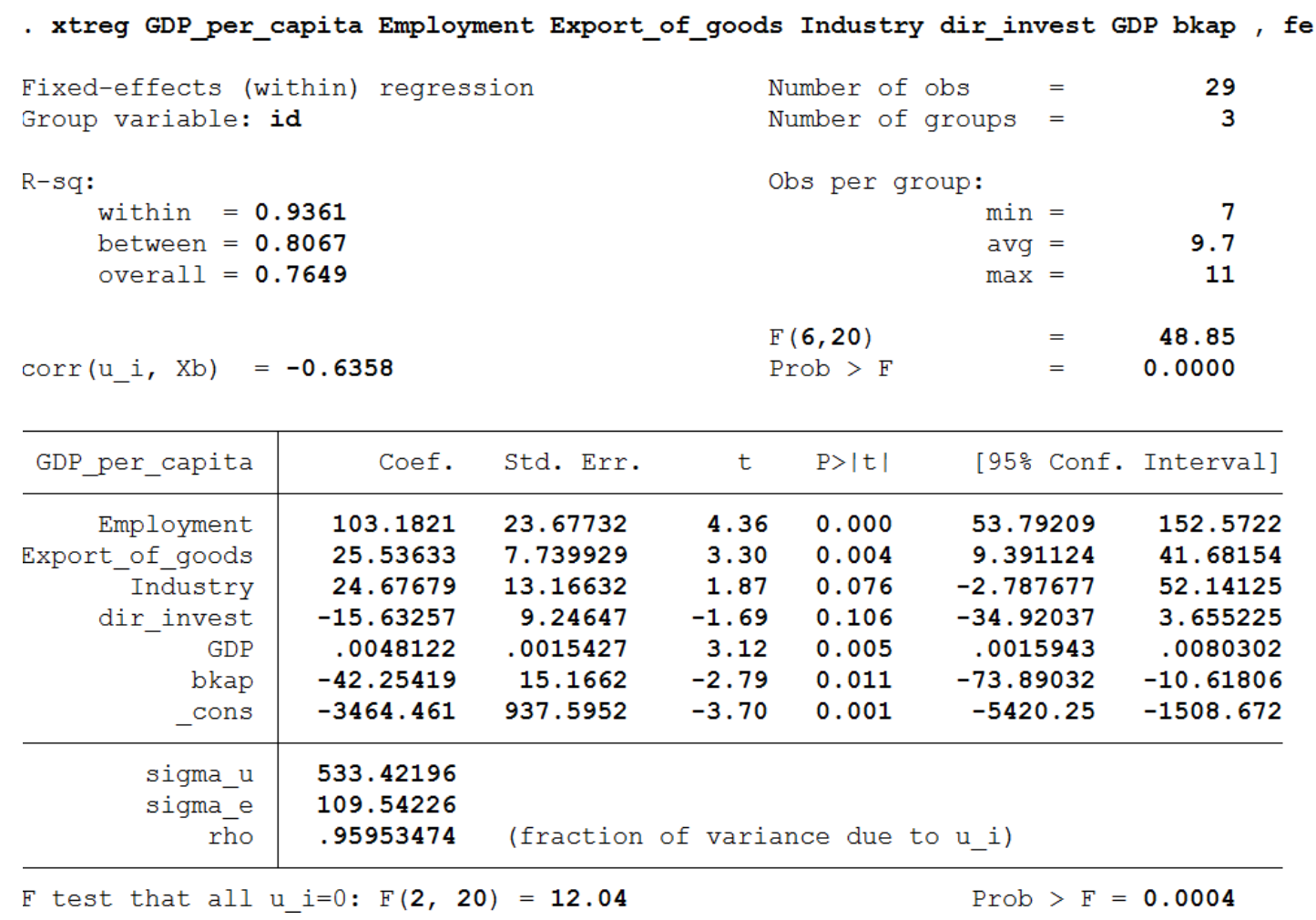

Figure 3. An assessment of the impact that theratio of bank capitaland reservestototal assets has oneconomic growth

The ratio of bank capital and reserves to total assets is statistically significant (0.01). For the group of the associate member countries, the indicator analyzed has the non-stimulant effect. It is likely that significant banking system capitalization distracts financial resources from the real sector of production, but it is only a hypothesis based on the obtained regression analysis. 


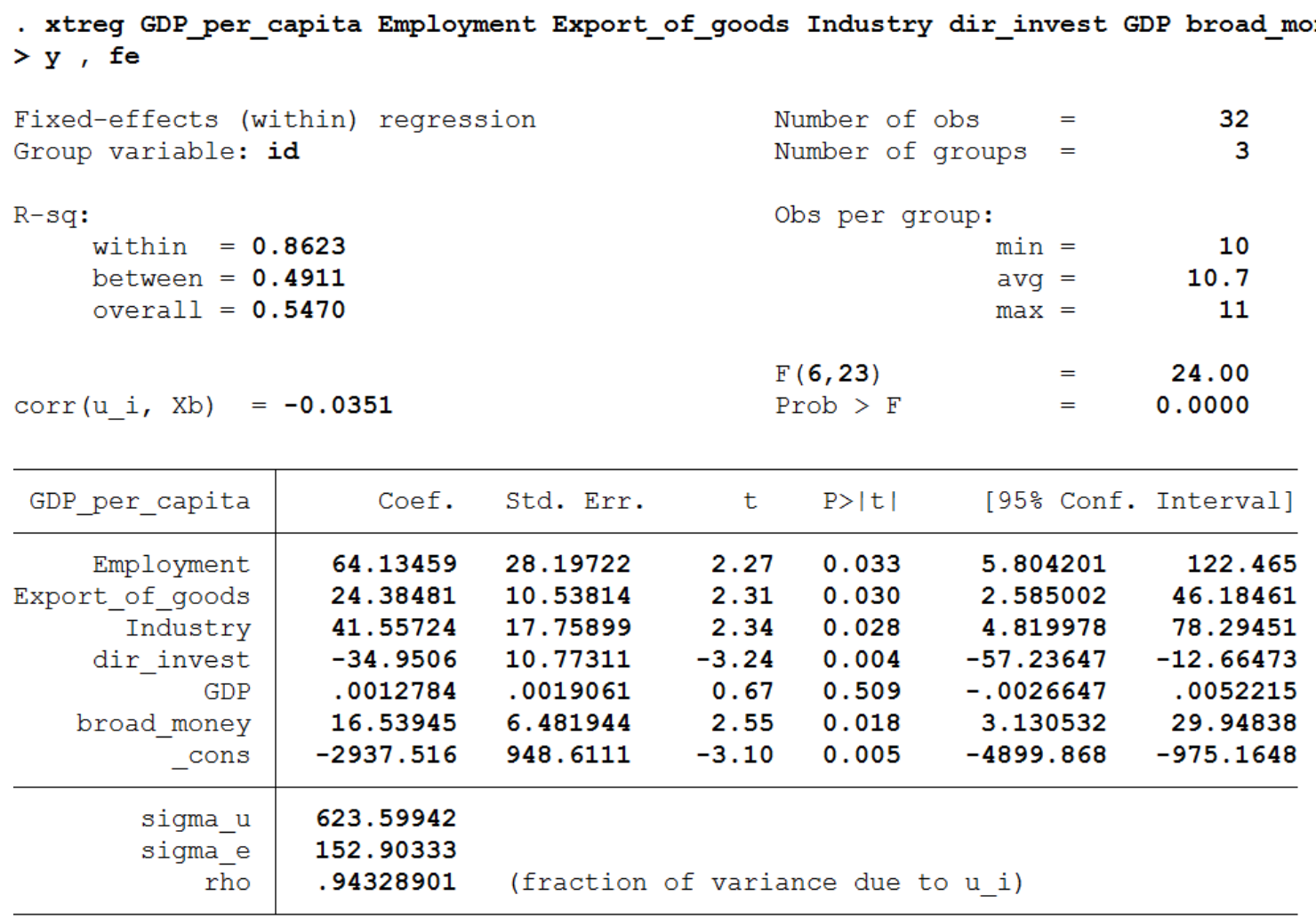

Figure 4. The results of the assessment of the M1 monetary aggregate share in GDP on the economic growth level

The second regression includes the share of M1 monetary aggregate in GDP. The M1 monetary aggregate in GDP has a positive effect on economic development in the group of countries in question. It is likely that a sufficient amount of cash in circulation is a factor of the normal conduct of business transactions between entities. According IMF studies, the level of the shadow economy of the studied countries in 1991-2015 is: Ukraine $-44.8 \%$ of GDP, Georgia $-64.87 \%$ of GDP, and Moldova $-43.4 \%$ of GDP. Shadowing the economy is one of the consequences of cash payments.

According to Voinov (2017), there is a positive correlation between the level of economic inequality and the financialization degree against the background of the lag of productive capacity. According to the author, an increase in the uneven distribution of income reduces the usefulness of economic growth and makes it unsustainable, which increases the systemic crisis risk. Let's analyze the regression dependence of the Gini index and economic development of the associate EU member states. The obtained regression dependence is marked by the negative influence of the index of the uneven distribution of income on economic growth $(-52.9)$. 


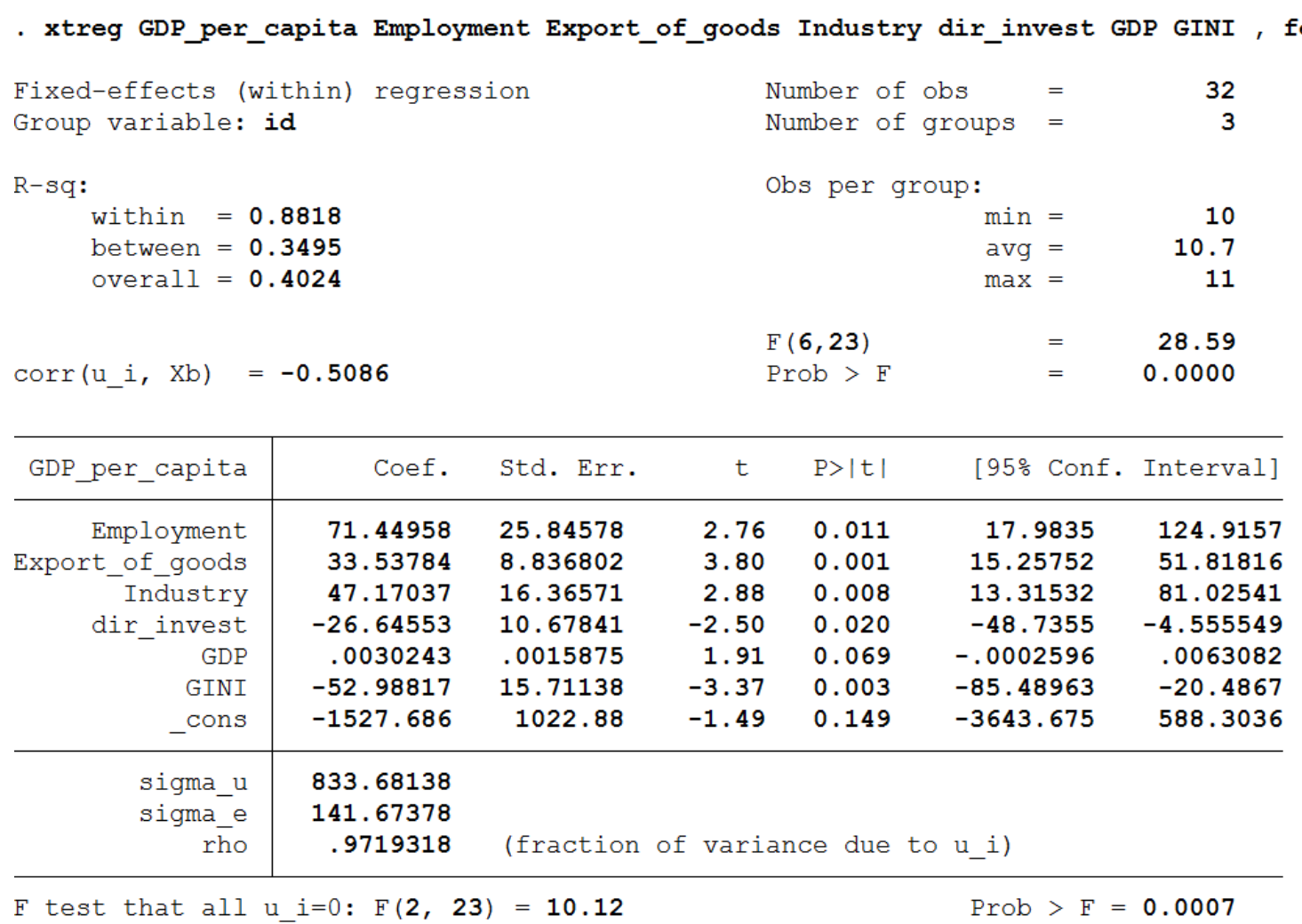

Figure 5. An assessment of the Gini index impact on economic growth

\section{Conclusion}

The countries under investigation that are associate EU members have similar characteristics, namely a shared historical past, a transition from the command and administrative economy to a market economy, and ongoing reform of the socio-political system. Besides, there is a lack of research in the scientific literature on reform countries with sufficient common characteristics to compare. These characteristics became the basis for the possible determination of common indicators of economic growth.

The regression obtained resulted in economic growthlargely dependent on employment rate. The factor of export of goods and services and the value added in production sector also play a significant role among the welfare factors of the selected countries. The negative impact of foreign direct investment is noted in this regression, which may be related to poor business conditions, lack of investor interests, corrupt and bureaucratic barriers.

Given that economy financialization in the countries studied is an integral part of their existence, the most statistically significant indicators of financializationhave been identified within the existing regression model of economic development. Among the indicators analyzed, the most notable were the ratio of the bank's capital and reserves to total assets, the share of the M1 monetary aggregate in GDP (\%), and Gini index. The banking sector, as the largest participant in the financial market, is expected to have an uneven relationship between equity and liabilities, which causes potential problems in the event of crises. The share of the monetary aggregate M1in GDP positively influences the level of economic development in the analyzed countries. This is due to the fact that a significant part of the transactions is conducted in cash, and at the same time, it is a risk factor for the shadow economy, as 
confirmed by the IMF'sshadowing indicators. The Gini index reaffirmed the suggestion that increasing uneven income distribution is driving economic decline.

\section{References}

Adelman, I., \& Morris, C. T. (1958). An Econometric Model of Socio-Economic and Political Change in Underdeveloped Countries. The American Economic Review, 58(5), 11841218.

Alvarez, I. (2015). Financialization, non-financial corporations and income inequality: The case of France. Socio-Economic Review, 13(3), 449-475. https://DOI:10.1093/ser/mwv007

Azarenkova, G., Shkodina, I., Samorodov, B., Babenko, M., \& Onishchenko, I. (2018). The influence of financial technologies on the global financial system stability. Investment Management and Financial Innovations, 15(4), 229-238. https://doi:10.21511/imfi.15(4).2018.19

Bakari, S., \& Mabrouki, M. (2017). Impact of Exports and Imports on Economic Growth: New Evidence from Panama. Journal of Smart Economic Growth, 2(1).

Barradas, R. (2019). Financialization and Neoliberalism and the Fall in the Labor Share: A Panel Data Econometric Analysis for the European Union Countries. Review of Radical Political Economics. https://doi.org/10.1177/0486613418807286

Bassanini, A., \&Scarpetta, S. (2001). The driving forces of economic growth: panel data evidence for the OECD countries. OECD Economic Studies, 33(2). Retrieved from https://www.oecd.org/eco/growth/18450995.pdf

Bijlsma, M., Kool, C., \& Non, M. (2017). The effect of financial development on economic growth: a meta-analysis (CPB Discussion Paper. No 340).

Bilan, Y., Gavurova, B., Stanisław, G., \& Tkacova, A. (2017). The Composite Coincident Indicator (CCI) for Business Cycles. Acta Polytechnica Hungarica, 14(7), 71-90.

Blakyta, G., Guliaieva, N., Vavdijchyk, I., Matusova, O., \&Kasianova, A. (2018). Evaluation of investment environment security in Ukraine. Investment Management and Financial Innovations, 15(4), 320-331. https://doi:10.21511/imfi.15(4).2018.26

Boldeanu, F. T., \& Constantinescu, L. (2015). The main determinants affecting economic growth. Bulletin of the Transilvania University of Braşov Series V: Economic Sciences, 8(57), 2, 329-338.

Boldyrev, Y., Chernogorskiy, S., Shvetsov, K., Zherelo, A., \& Kostin, K. (2019). A Mathematical Model of Regional Socio-Economic Development of the Russian Arctic Zone. Resources, 8, 45. https://doi.org/10.3390/resources8010045

Chirva, T. G., \&Odhiambo, N. M. (2016). Macroeconomic determinants of economic growth: a review of international literature. South East European Journal of Economics and Business, 11(2), 33-47. DOI: 10.1515/jeb-2016-0009

Dewan, E., \& Hussein S. (2001). Determinants of Economic Growth (Panel Data Approach). Economics Department Reserve Bank of Fiji, Working Paper, 1(4). Retrieved from http://www.rbf.gov.fj/docs/wp2001-04.pdf

Duman, A., \&Kureková, L. (2012). The role of state in development of socio-economic models in Hungary and Slovakia: The case of industrial policy. Journal of European Public Policy, 19(8), 1207-1228. DOI:10.1080/13501763.2012.709018 
Eddien, I., Ananzeh, N., \& Othman, M. D. (2019). Analyzing the effect of financial development on economic growth - the Jordanian experience. Investment Management and Financial Innovations, 16(1), 119-127. doi:10.21511/imfi.16(1).2019.09

Fifeková, E., \& Nemcová, E. (2015). Impact of FDI on Economic Growth: Evidence from V4 Countries. Periodica Polytechnica. Social and Management Sciences, 23(1), 7.

Gurgul, H., \& Lach, Ł. (2014). Globalization and economic growth: Evidence from two decades of transition in CEE. Economic Modelling, 36, 99-107.

Ilchenko, V., Goryaschenko, Y., Zhadko, K., \& Nekhay, O. (2019). Methodology of complex estimation level of socio-ecological and economic development of industrial regions of Ukraine. Problems and Perspectives in Management, 17(2), 277-288. DOI:10.21511/ppm.17(2).2019.21

Iyer, T., \& Gupta, A. S. (2019). Quarterly Forecasting Model for India's Economic Growth: Bayesian Vector Autoregression Approach. Asian Development Bank, 573. https://doi.org/10.22617/WPS190056-2

Karagiannis, S., \& Kvedaras, V. (2016). Financial development and economic growth (67 p.). Luxembourg: Publications Office of the European Union.

Kharlamova, G., Stavytskyy, A., Chernyak, O., Giedraitis, V., \& Komendant, O. (2019). Economic modeling of the GDP gap in Ukraine and worldwide. Problems and Perspectives in Management, 17(2), 493-509. https://doi:10.21511/ppm.17(2).2019.38

Kooros, S. K., \& Badeaux, L. M. (2007). Economic Development Planning Models: A Comparative Assessment. International Research Journal of Finance and Economics, 7, 120-139.

Korauš, A., Simionescu, M., \& Schönfeld, J. (2017). The impact of monetary variables on the economic growth and sustainable development: case of selected countries. Journal of $\begin{array}{llll}\text { Security and } \quad \text { Sustainability 383-390. } & \text { 385, }\end{array}$ https://doi.org/10.9770/jssi.2017.6.3(5)

Kozmenko, S., \& Korneev, M. (2014). Periodization of financialization process of economics: Domestic and foreign contexts. Economic Annals-XXI, 9-10, 73-76.

Kozmenko, S., \& Korneyev, M. (2017). Formalization of the impact of imbalances in the movement of financial resources on economic growth of countries in Central and Eastern Europe. Accounting and Financial Control, 1(1), 48-58. https://doi.org/10.21511/afc.01(1).2017.06

Kvasha, S., Davydenko, N., Pasichnyk, Y., Viatkina, T., \& Wasilewska, N. (2018). GDP modelling: assessment of methodologies and peculiarities of its usage in Ukraine. Problems and Perspectives in Management, 16(4), 186-200. https://doi.org/10.21511/ppm.16(4).2018.16

Liashenko, O. I. (2013). Solow-Swan model of economic growth with neutral, capital intensive and labor intensive technological progress. Efektyvna ekonomika, 6. Retrieved from http://www.economy.nayka.com.ua/?op=1\&z=2123

Lychkina, N. N. (2004). Simulation modeling of regions' social and economic development in decision support systems (pp. 28-30). III International conference "System identification and control problems". Retrieved from https://www.systemdynamics.org/assets/conferences/ 2009/proceed/papers/P1068.pdf

Malik, K. (2015). Impact of foreign direct investment on economic growth of Pakistan. American Journal of Business and Management, 4(4), 190-202. 
Malyovanyi, M., Ivanova, N., Melnyk, K., Nepochatenko, O., \& Rolinskyi, O. (2018). Assessment of the social expenditure impact on the economic growth in OECD countries. Problems and Perspectives in Management, 16(3), 389-405. https://doi.org/10.21511/ppm.16(3).2018.31

Masoud, N., \& Hardaker, G. (2012). The impact of financial development on economic growth: Empirical analysis of emerging market countries. Studies in Economics and Finance, 29(3), 148-173. https://doi.org/10.1108/10867371211246830

Mercado, P. R., \& Cicowiez, M. (2013). Growth Analysis in Developing Countries: empirical issues and a small dynamic model. Munich Personal RePEc Archive. Retrieved from https://mpra.ub.uni-muenchen.de/58017/

Osuji, O. (2015). Financial Development and Economic Growth in Nigeria. Journal of Economics and Sustainable Development, 6(20), 26-40.

Peralta, I., \& Escalonilla, F. (2011). Financialization, capital accumulation and wage growth in the EU-15. InvestigacionEconomica, 70(276), 125-162.

Petkovski, M., \& Kjosevski, J. (2013). Does banking sector development promote economic growth? An empirical analysis for selected countries in Central and South Eastern Europe. Economic Research-Ekonomska Istrazivanja, 27(1), 55-66. https://DOI:10.1080/1331677X.2014.947107

Saseendran, P., \& Rodríguez, M. C. M. (2018). Human Development for Socio Economic Transformation. The Kerala Development Model, India (pp. 112-120). I Congreso Virtual InternacionalsobreEconomía Social y Desarrollo Local SostenibleEnero. Retrieved from https://www.eumed.net/actas/18/economia-social/8-humandevelopment.pdf

Shkolnyk, I., Melnyk, T., \& Mershchii, B. (2018). Transparency of the budget process as a prerequisite for financial decentralization in Ukraine. Public and Municipal Finance, 7(1), 12-20. https://DOI:10.21511/pmf.07(1).2018.02

Simionescu, M., Lazányi, K., Sopková, G., Dobeš, K., \& Balcerzak, A. (2017). Determinants of Economic Growth in V4 Countries and Romania. Journal of Competitiveness, 9(1), 103-116. https://doi.org/10.7441/joc.2017.01.07

Simionescu, M., Ciuiu, D., Bilan, Y., \& Strielkowski, W. (2016). GDP and net migration in some eastern and south-eastern countries of Europe. A panel data and Bayesian approach. Montenegrin Journal of Economics, 12(2), 161-175.

Smirnov, R. G., \& Wang, K. (2018). In search of a new economic model determined by logistic growth. Cornell University. Retrieved from https://arxiv.org/abs/1711.02625

Solow, R. M. (1956). A Contribution to the Theory of Economic Growth. Oxford Review of Economic Policy, 23(1), 3-14.

Svilokos, T., \& Burin, I. (2017). Financialization and its impact on process of deindustrialization in the EU. Zbornik Radova Ekonomskog Fakultet au Rijeci, 35(2), 583-610. https://doi.org/10.18045/zbefri.2017.2.583

Swan, T. W. (1956, November). Economic Growth and Capital Accumulation. Economic Record, 32, 334-361.

Szirmai, A. (2005). The Dynamics of Socio-Economic Development. An Introduction Cambridge University Press.

The Royal Swedish Academy of Sciences. (2018). Scientific Background on the SverigesRiks bank Prize in Economic Sciences in Memory of Alfred Nobel 2018. Economic Growth, 
Technological Change, and Climate Change. Retrieved from https://www.nobelprize.org/uploads/2018/10/advanced-economicsciencesprize2018.pdf

Torres-Reyna, O. (2007). Panel Data Analysis: Fixed and Random Effects using STATA. Princeton University. Retrieved from http://dss.princeton.edu/training

Vinnychuk, O., Grygorkiv, V., \& Biloskurskii, R. (2015). The dynamic model of optimal economic growth in terms of ecological balance: models construction and results analysis. Verslo Sistemosr Ekonomika. Business Systems and Economics, 5(1), 36-45.

Vladychyn, U., Skomorovych, I., \& Lobozynska, S. (2018). Assessment of financial and economic security of Ukraine in conditions of foreign banking development. Banks and Bank Systems, 13(3), 151-173. https://doi.oorg/10.21511/bbs.13(3).2018.15

Voinov, E. (2017). Dependency between inequality and economic growth: new approach and its empiric corroboration. Problems of Modern Economics, 3(63), 52-55. 


\section{APPENDIX A}

Table A1. Statistical 2007-2017indicators of the associate EU members

\begin{tabular}{|c|c|c|c|c|c|c|c|c|}
\hline Country & Year & $\begin{array}{c}\text { GDP } \\
\text { per } \\
\text { capita }\end{array}$ & $\begin{array}{c}\text { Employment } \\
\text { to population } \\
\text { ratio, 15+, } \\
\text { total (\%) } \\
\text { (modeled ILO } \\
\text { estimate) }\end{array}$ & 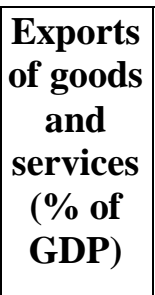 & $\begin{array}{c}\text { Industry } \\
\text { (including } \\
\text { construction), } \\
\text { value added } \\
\text { (\% of GDP) }\end{array}$ & 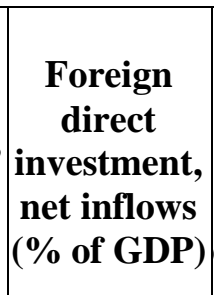 & $\begin{array}{c}\text { GINI } \\
\text { index } \\
\text { (World } \\
\text { Bank } \\
\text { estimate) }\end{array}$ & $\begin{array}{c}\text { Bank } \\
\text { capital to } \\
\text { assets ratio } \\
(\%)\end{array}$ \\
\hline UKR & 2007 & 3220.0 & 51.38 & 42.46 & 32.38 & 7.15 & 29.8 & 11.5 \\
\hline UKR & 2008 & 3311.9 & 51.35 & 44.43 & 29.25 & 5.95 & 27 & 12.8 \\
\hline UKR & 2009 & 2834.3 & 50.07 & 43.91 & 25.85 & 4.07 & 26.6 & 13.0 \\
\hline UKR & 2010 & 2965.1 & 50.53 & 47.05 & 25.90 & 4.74 & 25.3 & 14.6 \\
\hline UKR & 2011 & 3138.4 & 50.88 & 49.82 & 25.11 & 4.42 & 24.8 & 14.7 \\
\hline UKR & 2012 & 3153.7 & 50.77 & 47.72 & 24.54 & 4.65 & 24.6 & 15.0 \\
\hline UKR & 2013 & 3160.0 & 51.55 & 42.96 & 22.67 & 2.46 & 24.7 & 15.0 \\
\hline UKR & 2014 & 3123.9 & 49.25 & 48.59 & 22.82 & 0.63 & 24.6 & 11.2 \\
\hline UKR & 2015 & 2828.8 & 49.58 & 52.60 & 21.73 & 3.35 & 24 & 8.0 \\
\hline UKR & 2016 & \begin{tabular}{|l|}
2905.8 \\
\end{tabular} & 49.35 & 49.30 & 23.18 & 3.69 & 25.5 & 9.7 \\
\hline UKR & 2017 & 2991.6 & 49.08 & 47.95 & 23.99 & 2.52 & 25 & 11.9 \\
\hline MDA & 2007 & 1497.1 & 43.40 & 45.26 & 18.78 & 12.18 & 34.4 &.. \\
\hline MDA & 2008 & 1616.9 & 42.57 & 45.58 & 19.44 & 12.00 & 34.7 &.. \\
\hline MDA & 2009 & 1521.8 & 40.17 & 40.82 & 19.12 & 4.75 & 32.9 & 16.0 \\
\hline MDA & 2010 & 1631.5 & 38.87 & 36.87 & 17.16 & 4.92 & 32.1 & 15.9 \\
\hline MDA & 2011 & 1743.4 & 39.49 & 39.23 & 17.08 & 4.96 & 30.6 & 15.8 \\
\hline MDA & 2012 & 1731.5 & 38.48 & 44.97 & 17.63 & 3.44 & 29.2 & 17.2 \\
\hline MDA & 2013 & 1894.7 & 39.36 & 43.48 & 17.81 & 3.03 & 28.5 & 15.0 \\
\hline MDA & 2014 & 1986.9 & 39.71 & 43.34 & 18.12 & 4.28 & 26.8 & 13.1 \\
\hline MDA & 2015 & 1980.2 & 42.47 & 41.53 & 18.66 & 3.32 & 27 &.. \\
\hline MDA & 2016 & 2070.6 & 41.01 & 42.80 & 18.84 & 1.40 & 26.3 & 17.3 \\
\hline MDA & 2017 & 2165.1 & 40.56 & 43.46 & 18.51 & 1.98 & 25.9 & 17.0 \\
\hline GEO & 2007 & 2719.3 & 55.01 & 31.21 & 20.90 & 18.48 & 38.1 & 20.4 \\
\hline GEO & 2008 & 2821.0 & 53.08 & 28.62 & 18.94 & 12.48 & 38.5 & 17.1 \\
\hline GEO & 2009 & 2753.6 & 52.97 & 29.74 & 18.93 & 6.11 & 38.2 & 18.2 \\
\hline GEO & 2010 & \begin{tabular}{|l|}
2964.4 \\
\end{tabular} & 54.28 & 34.95 & 19.32 & 7.74 & 39.5 & 16.9 \\
\hline GEO & 2011 & 3220.3 & 56.04 & 36.24 & 20.51 & 8.08 & 39.6 & 16.5 \\
\hline GEO & 2012 & 3469.6 & 57.12 & 38.15 & 21.07 & 5.95 & 39 & 16.6 \\
\hline GEO & 2013 & 3633.7 & 56.96 & 44.69 & 20.88 & 6.37 & 38.6 & 16.7 \\
\hline GEO & 2014 & \begin{tabular}{|l|}
3851.7 \\
\end{tabular} & 58.83 & 42.94 & 20.64 & 11.01 & 37.6 & 17.3 \\
\hline GEO & 2015 & \begin{tabular}{|l|}
3973.2 \\
\end{tabular} & 59.97 & 44.74 & 21.33 & 11.86 & 36.5 & 13.9 \\
\hline GEO & 2016 & \begin{tabular}{|l|l}
4083.9 \\
\end{tabular} & 59.56 & 43.60 & 21.45 & 10.92 & 36.6 & 13.1 \\
\hline GEO & 2017 & \begin{tabular}{|l|}
4283.9 \\
\end{tabular} & 59.79 & 50.27 & 22.64 & 12.13 & 37.9 & 12.8 \\
\hline
\end{tabular}

